\title{
Unusual shell anatomy and osteohistology in a new Late Cretaceous panchelid turtle from northwestern Patagonia, Argentina
}

Marcelo S. De La Fuente, Ignacio Maniel, Juan Marcos Jannello, Juliana Sterli, Alberto C. Garrido, Rodolfo A. Garcia, Leonardo Salgado, José I. Canudo, and Raúl Bolatti

Acta Palaeontologica Polonica 62 (3), 2017: 585-601 doi:https://doi.org/10.4202/app.00340.2017

Rionegrochelys caldieroi de la Fuente, Maniel, and Jannello gen. et sp. nov. is a Late Cretaceous turtle from Rio Negro Province, Argentina. The holotype and the referred specimens of this new species show an unusual shell morphology and microanatomy. The proportion between the carapace and plastron and the peculiar morphology of the shell such as the heart shaped carapace, a very deep nuchal notch, peripheral bones 2-11 with strongly gutter, the first vertebral scute twice as wide as long and subrectangular in shape, the posterior margin of vertebral scute 5 is three lobe shaped, and the unexpected osteohistology characterized by a massive structure, with higher compactness (80.6\%) than other chelids, suggests beyond doubt that this turtle may be considered a new taxon. A semi-aquatic habitat with tendency towards terrestrial environments is inferred for Rionegrochelys caldieroi similar to that of the extant pelomedusid Pelomedusa subrufa among the extant pleurodires. Rionegrochelys caldieroi is recovered as a stem chelid. This new species seems to be closely related to Bonapartemys bajobarrealis and the clade formed by Lomalatachelys neuquina plus Mendozachelys wichmanni.

Key words: Testudines, Pleurodira, post-cranial morphology, paleohistology, Cretaceous, Argentina, Río Negro.

Marcelo S. de la Fuente [mdelafuente1910@gmail.com], Ignacio Maniel [nachomaniel@ gmail.com ], Juan Marcos Jannello [marcosjannello@ hotmail.com], Grupo Vinculado al IANIGLA CCT-Mendoza, Museo de Historia Natural de San Rafael, Av. Balloffet $\mathrm{S} / \mathrm{N}^{\circ}$ frente al Parque Mariano Moreno, 5600 San Rafael, Mendoza, Argentina. Juliana Sterli [jsterli@mef.org.ar], Museo Paleontológico Egidio Feruglio, Av. Fontana 140, 9100 Trelew, Chubut, Argentina. Alberto C. Garrido [albertocarlosgarrido@gmail.com], Museo Provincial de Ciencias Naturales "Prof. Dr. Juan Olsacher", Dirección General de Minería Elena de Vega 472, 8340 Zapala, Neuquén, Argentina. Rodolfo A. García [rodosnow@yahoo.com.ar ], Instituto de Investigación en Paleobiología y Geología, Universidad Nacional de Rio Negro, Museo Provincial Carlos Ameghino, Belgrano 1700, Paraje Pichi 
Ruca (predio Marabunta) R8324CZH Cipolletti, Río Negro, Argentina. Leonardo Salgado [1salgado@unrn.edu.ar], Instituto de Investigación en Paleobiología y Geología, Universidad Nacional de Rio Negro, Gral Roca, Rio Negro, Argentina. José I. Canudo [jicanudo@ unizar.es] Grupo Aragonsaurus-IUCA, Facultad de Ciencias, Universidad de Zaragoza 50009 Zaragoza, Spain. Raúl Bolatti [rbolatti@ hotmail.com], Unidad de Gestión Margen Sur, Municipalidad de Cipolletti, R8324CZH Cipolletti, Río Negro, Argentina.

This is an open-access article distributed under the terms of the Creative Commons Attribution License (for details please see creativecommons.org), which permits unrestricted use, distribution, and reproduction in any medium, provided the original author and source are credited.

Forit) Full text $(1.418 .6 \mathrm{kB})$

For Supplementary file $(175.2 \mathrm{kB})$ 